[計 測 自 動制 御 学 会 論文集]

[ Vol.48, No.7, 431/440 (2012) ]

\title{
円制限三体問題のラグランジュポイントの安定性に関する \\ 陰的制御的考察
}

\author{
坂 東 麻 衣*.大須賀 公一** \\ 藤井隆 雄 ${ }^{* * *} \cdot$ 山宏***
}

Implicit Control Structure in Lagrangian Points of Circular-restricted Three-body Problem

\author{
Mai BANDO*, Koichi OsukA**, \\ Takao Fujir*** and Hiroshi YAmaKaWA ${ }^{* * * *}$
}

\begin{abstract}
If two bodies move in circular orbits about their common centre of mass and the mass of the third body is too small to affect the motion of the other two bodies, the problem of the motion of the third body is called circular restricted three-body problem (CR3BP). This system has five equilibrium points which is known as Lagrangian points. Among five equilibrium points, $L_{4}$ and $L_{5}$ Lagrangian points are stable while $L_{1}, L_{2}$ and $L_{3}$ are unstable. In this paper, we consider the motion in the vicinity of the $L_{4,5}$ Lagrangian points where the implicit control structure provides an insight into the control structure underlying the problem.
\end{abstract}

Key Words: three-body problem, implicit control, inverse problem of optimal control

\section{1.はじめに}

太陽一地球一月のように，お互いに相互作用する 3 つの物体 の運動を扱う問題を 3 体問題という. 3 つ目の物体の質量が 他の 2 体の運動に影響を及ぼさないほど小さい場合の, 3 体 目の運動を考える問題を制限 3 体問題という. 特に, 共通重 心のまわりを円運動する 2 つの天体からの万有引力をうける， 十分に小さい質点の運動を考える問題は円制限三体問題とよ ばれ，ラグランジュポイントとよばれる 5 つの平衡点が存在 することが知られている ${ }^{1)}$. 5 つのラグランジュポイントの うち, 2 天体を結ぶ直線上にある $L_{1}, L_{2}, L_{3}$ 点はすべて不安 定であるのに対し， 2 天体を底辺とする正三角形の頂点にある $L_{4}, L_{5}$ 点は (リアプノフの意味で) 安定な平衡点である. 実 際, 太陽一木星系の $L_{4}$ 点にはトロヤ群と呼ばれる小惑星群が

* 京都大学宇宙総合学研究ユニット 宇治市五ケ庄

** 大阪大学大学院工学研究科 吹田市山田丘 2-1

**** 福井工業大学経営情報学科 福井市学園 3-6-1

**** 京都大学生存圈研究所 宇治市五ケ庄

* Unit of Synergetic Studies for Space, Kyoto University, Gokasho, Uji

** Graduate School of Engineering, Osaka University, 2-1 Yamadaoka, Suita

*** Department of Management Information Science, Fukui University of Technology, 3-6-1 Gakuen, Fukui

**** Research Institute for Sustainable Humanosphere, Kyoto University, Gokasho, Uji

(Received April 1, 2011)

(Revised April 24, 2012)

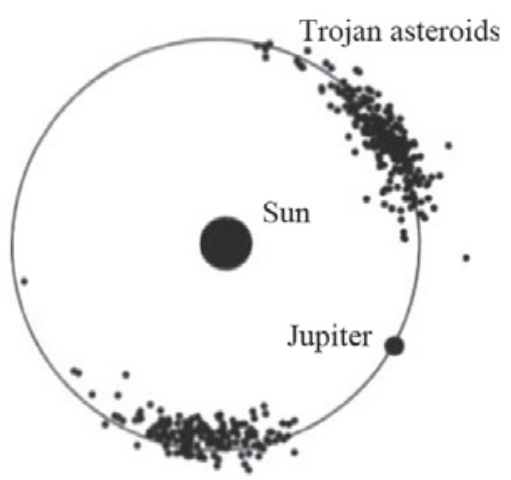

Fig. 1 Trojan asteroids

存在することが知られており ${ }^{2)}$ ，トロヤ群のように $L_{4}$ 点に位 置する小惑星は他の太陽-惑星系にも存在している (Fig. 1). また, 2 つの重心により近似されるピーナッツ型の形状をも つ小惑星 $(\text { Fig. 2 })^{3)}$ 近傍の $L_{4,5}$ 点に置かれた物体の運動も また円制限三体問題と同様の安定性をもつことが知られてい $3^{4), 5)} . L_{4,5}$ 点は, 2 質点の重力場と遠心力を導く回転運動 の場のポテンシャルを考えたとき，その極大点となっている. このことから, 通常, 安定な平衡点はポテンシャルの極小点 で, 平衡点からの微小变位は運動エネルギーの減少をもたら すのに対し， $L_{4,5}$ 点においては，それとは逆のメカニズムによ り安定化されていることがわかる。本研究では, 円制限三体 問題の $L_{4,5}$ 点の安定性を陰的制御の観点から考察する. 本稿 では, 力学現象である円制限三体問題におけるラグランジュ ポイントの安定性の表出を, あえて制御則が内在しているか 


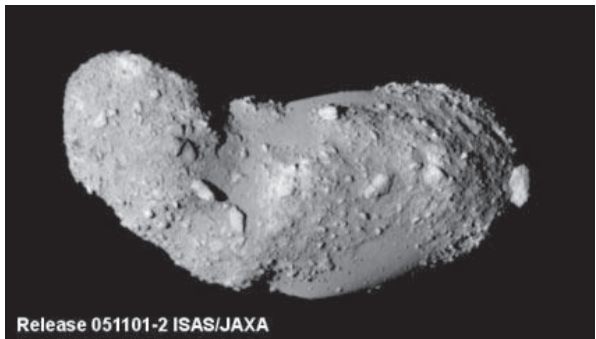

Fig. 225143 Itokawa $^{3)}$

らだという捉え方をする，そのような見方をすることで，天 体の運動に対してこれまでとは違った思考が生まれ，新たな 展開が期待できると考えられる，そのための第一歩としてこ こでは，(i) 想定する陰的制御に何らかの意味があるか，(ii) 陰的制御に陽的制御を付加したものに何らかの意味をもたせ ることができるか, について考察する.

構成は以下のとおりである．2 章で，陰的制御という考え 方を導入する. 3 章では, 円制限三体問題とその平衡点につ いて説明する. 4 章では, 円制限三体問題における陰的制御 として，3つの状況を考える．5章では，4章で考えた陰的制 御の最適性について論じ，さらに陽的制御を付加することで 漸近安定化をする際に生まれる差異について述べる。6 章は まとめとし，陰的制御を導入することで示唆される結論と今 後の展開について考察する.

\section{2. 陰的制御}

\section{1 陰的制御の定義}

本章では天体力学と制御工学との橋渡しの役割を担う陰的 制御の考え方を紹介する.

一般に何かを制御する場合，「まず制御対象が与えられ，つ ぎに制御則が装着され，そして制御系が構成される」という流 れを考える. もちろん, そのような過程を踏むこともあるが, たとえば生物の制御系を考え，そこから思いを巡らせてみる と, 制御系における制御対象と制御則の境界は不明瞭であり, さらには制御対象と環境との境界も果たして明確に区別でき るのだろうかという疑問が湧き出てくる．さらによく考えて みると, 生物に限らず人工物あるいは広く自然物であっても, 必ずしも，はじめに制御対象が用意されてそこに制御則が装 着された結果制御系が構成されたわけではなく, 同時発生的 に制御系が構成されたとみなすことができる場合も多々ある. すなわち, これら三者 (制御対象, 制御則, 環境) は区別で きないほうがむしろ自然である場合がある。したがって，そ のような考え方で一般的な制御系をブロック線図で表現しよ うとすると（通常のブロック線図ではなく），Fig. 3 のよう になるという捉え方が成り立つ。

さて,このような議論をより深く進めるにあたって, 議論展 開が不明確にならないためには, 制御対象や制御則などの用 語を改めて定義しておかねばならない. そしてそのためには, 定義の起点として, その対象物を注目している「主体とその意

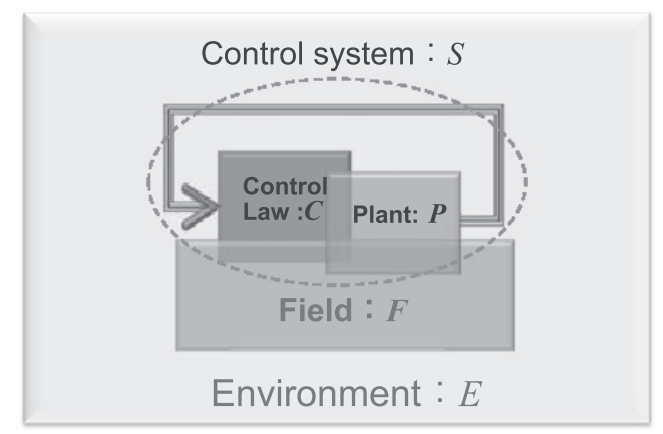

Fig. 3 General structure of control system

罒」の存在を仮定することからはじめよう ${ }^{6)}$. その上でまず, すべてが含まれている空間全体を「環境：E (Environment)」 とする，その中に，主体の「意図（あるいはそれによって生 成された運動目的) $: T$ (Task)」が存在し, それに従って運動 させたいと意図されている考察の対象が存在しているとする.

このとき, その対象のことを「制御対象：P (Plant)」と呼 ぶ.すなわち

$$
P=\mathcal{P}(T)
$$

である。そして, 環境の一部分であって制御対象 $P$ を含み, かつ, 特にいま注目している意図 $T$ に直接関連し, その意図 の達成に効果的に働く集合が存在する場合, それを「場：F (Field)」と定義する．環境 $E$ は主体とその意図 $T$ とは無関 係に存在しているが，場 $F$ は意図 $T$ や制御対象 $P$ に依存し て存在・不存在が定まることがあり，あるいは，物理的には 存在していても意図 $T$ に因って場 $F$ としての意味が表出し たり消失したりすると考えている。すなわち

$$
F=\mathcal{F}(E, T, P)
$$

である．上式における $T$ や $P$ の寄与度は場合によって異な る.またいうまでもなく, 環境 $E$ の変化に応じて場 $F$ も変 化する。 つぎに, 意図 $T$, 場 $F$, 制御対象 $P$ が存在する中 で, 制御対象 $P$ を意図 $T$ にそって運動させるのに有効に働 く要素がある場合, それを「制御則 $C$ (Control Law)」と呼 ぼう。すなわち

$$
C=\mathcal{C}(T, F, P)
$$

である。

最後に, 場 $F$, 制御対象 $P$, 制御則 $C$ をあわせた全体を 「制御系 $S$ (Control system)」と呼ぶ.すなわち

$$
S=\mathcal{S}(F, P, C)
$$

である。

われわれはこれまでに, いくつかの事例を考察し発展させ た結果, Fig. 3 で表現されている「要素間の重なり」を, そ れらの間に「制御則的な働きを果たす何らかの要素が挟み込 まれている」と捉えることで形式的に分離することが一つの 有効な考え方であろうという推察を得るに至った。すなわち， 


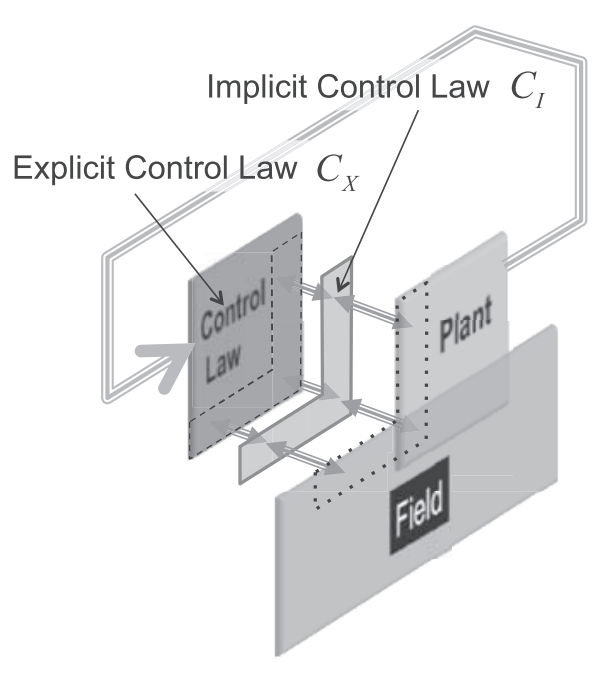

Fig. 4 Implicit and explicit control law

Fig. 3 のように見える制御系を Fig. 4 のように見なすこと を提案している6),7).

そして,もし何らかの制御則が埋め込まれていると見なせ るならば，その部分の制御則をつぎのように定義しよう。

定義 2.1. 陰的制御則と陽的制御則: 意図 $T$, 制御則 $C$ と制御 対象 $P$ あるいは場 $F$ との相互作用の結果, 制御対象や場にあ る種の制御則が存在するとみなされるとき, その制御則を「陰 的制御則 $C_{I}$ (Implicit Control Law)」と呼び, 制御則から陰 的制御則を除いたものを「陽的制御則 $C_{X}$ (Explicit Control Law)」と呼ぶ. すなわち, 制御則 $C$ (Control Law) は陰的 制御則と陽的制御則の合成で構成される(注 1 ). 次式参照.

$$
C=C_{I} \bigoplus C_{X}
$$

演算 $A \oplus B$ は要素 $A$ と $B$ との間に共通要素がないとした ときの複合を意味するものとする。

\section{2 陰的制御に関する考察}

本節では, 次章以降の議論を想定して, 陰的制御と陽的制 御の働きについて，簡単な例を使って考察する.

具体例として,たとえば不安定な制御対象

$$
<S>: \quad \dot{x}=a x
$$

を考え ( $a$ は定数), 以下では $<S>$ を漸近安定化する過程 を段階的に構築してみよう。

まず，制御対象 $<S>$ と場との相互作用によって，陰的制 御則が生まれ，つぎのようなシステムになっているとする.

$$
<S_{1}>: \quad \dot{x}=(a+f) x
$$

ただし， $f$ は適当な定数であり，これが陰的制御則のゲイン になっており, この効果によって, 制御対象 $<S>$ はある 程度安定になっているとする，すなわち，㓌的制御則はもと

(注 1）この考え方は自律分散システム ${ }^{8)}$, 創発システム ${ }^{9)}$, そ して移動知 ${ }^{10)}$ の研究の流れをくむものである.
もと不安定であった制御対象をできるだけ安定化することは できるが漸近安定にするほどの能力はないという状況を想定 する.

そこでつぎにわれわれは，本システムに陽的制御 $u$ を加え られるようにすることで $<S_{1}>$ を漸近安定化することを目 指す。すなわち，

$$
<S_{2}>: \quad \dot{x}=(a+f) x+u
$$

なるシステムを構築し， $<S_{2}>$ の安定化を考えるとしょう. ここで，陽的制御 $u$ の設計には自由度があるが，たとえばつ ぎの評価関数 $(q>0)$

$$
J=\int_{0}^{\infty}\left(q x^{2}+u^{2}\right) d t
$$

に対する最適制御則を求めることは合理的であろう。そうす ると, 本問題に対する最適制御則 (陽的制御) は次式のよう に求まる.

$$
u=u_{2}=-k_{2} x
$$

ただし，

$$
k_{2}=a+f+\sqrt{(a+f)^{2}+q}
$$

である。

$$
\begin{aligned}
& \text { さて, ここでつぎのシステムを考えよう. } \\
& <S_{3}>: \quad \dot{x}=a x+\left(f x+u_{2}\right)
\end{aligned}
$$

本システムは，陰的制御則と付加的に設計した陽的制御則を あわせた制御則が，もともとの制御対象に対してどのような 意味があるか（意味をもたせることができるか）を検討する ためのシステム表現である.すなわち, 制御対象 $\langle S>$ に 対して入力

$$
u_{3}=f x+u_{2}=-k x
$$

を考える。ただし，

$$
\begin{aligned}
k & =-f+\left(a+f+\sqrt{(a+f)^{2}+q}\right) \\
& =a+\sqrt{(a+f)^{2}+q}
\end{aligned}
$$

である。

$$
\text { これが, }
$$

$$
<S_{3}^{*}>: \quad \dot{x}=a x+u
$$

の何らかの最適制御になっているかを確認しょう (逆最適). それには, 上の制御則ゲイン $k$ が, 未知定数 $q_{x}>0$ を含む 評価関数

$$
J_{x}=\int_{0}^{\infty}\left(q_{x} x^{2}+u^{2}\right) d t
$$

を考えたときの最適制御則ゲイン

$$
k_{x}=a+\sqrt{a^{2}+q_{x}}
$$

と一致するような定数 $q_{x}>0$ が逆算できればよい. そこで, 
$k=k_{x}$ とおくことにより, 求めるべき $q_{x}$ が満たすべき関係 式がつぎのように求まる。

$$
q_{x}=f^{2}+2 a f+q>0
$$

ただし，本式は常に成り立つものではない，本式が成り立つ ための必要十分条件は, 本式は $f$ の 2 次方程式とみなすこと ができるので,

$$
D=a^{2}-q
$$

とすれば，つぎの 2 つのケースが得られる.

Case $1 D<0\left(a^{2}<q\right)$ のときは $f$ にかかわらず常に $q_{x}>0$ となり, その結果, $k$ は $<S_{3}^{*}>$ に対する最適ゲイ ンになっている。

Case $2 \quad D \geq 0\left(a^{2} \geq q\right)$ のときは

$$
f \leq-a-\sqrt{a^{2}-q}
$$

のとき $q_{x}>0$ となるので, 本条件を満たすとき $k$ は $<S_{3}^{*}>$ に対する最適ゲインになっている(注 2).

以上からいえることは，つぎのようなことである。「ある制 御対象 $(<S>)$ に対して陰的制御を加えたもの $\left.\left(<S_{1}\right\rangle\right)$ に対して陽的制御として最適制御則を設計したとき，その入 力と陰的制御による入力もあわせたものが元の制御対象に対 して最適になっていることがある。年の条件は，(i) $<S_{1}>$ に対する最適制御を考えるときの評価関数において状態に対 する重み $q$ の值が大きいときは常に最適ゲインとなる（定量 的には Case 1), (ii) $q$ の值が小さいときは， $f$ の大きさに制 限が加わる（定量的には Case 2)，のいずれかが成り立つこ とである.」

\section{3. 円制限三体問題}

\section{1 円制限三体問題}

質量が $m_{1}, m_{2}$ の天体からの引力のもとで運動する質点 $m$ の物体の運動を考える. $m$ が $m_{1}, m_{2}$ に比べ十分小さいと き，2つの質点は二体問題の解であるケプラー運動を行なう. このように，3体のうち 1 体の質量をゼロと考え，質量ゼロ の天体はこの 2 体の引力のもとで運動を行なうとする問題を 制限三体問題という（詳しい導出は付録を参照）．特に 2 つの 質点の運動が円運動である場合を円制限三体問題という。円 運動の角速度を $\Omega$ とすると，2 質点の重心に固定した回転座 標系における質点 $m$ の物体の運動方程式は,

$$
\begin{gathered}
\ddot{x}-2 \Omega \dot{y}-\Omega^{2} x=-\frac{G m_{1}}{r_{1}^{3}}(x+\mu d)-\frac{G m_{2}}{r_{2}^{3}}[x-(1+\mu) d] \\
\ddot{y}+2 \Omega \dot{x}-\Omega^{2} y=-\frac{G m_{2}}{r_{1}^{3}} y-\frac{G m_{2}}{r_{2}^{3}} y \\
\ddot{z}-\frac{G m_{1}}{r_{1}^{3}} z-\frac{G m_{2}}{r_{2}^{3}} z
\end{gathered}
$$

(注 2) 条件 $f>-a+\sqrt{a^{2}-q}$ も出てくるが今の問題設定に おいては無意味であるので外す。

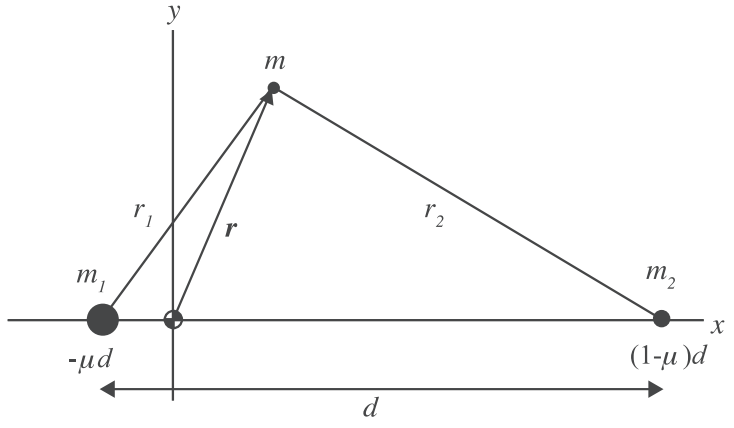

Fig. 5 Restricted three-body problem

である ${ }^{1), 2)}$.ここで $m_{1}, m_{2}$ は 2 天体の質量, $G$ は万有引力 定数, $\mu=m_{2} /\left(m_{1}+m_{2}\right)$ は質量比, $d$ は 2 天体の間の距離 であり，座標系の原点は天体の重心にとった（Fig. 5)。擬似 ポテンシャル $W$ を

$$
\begin{aligned}
W & =U+\frac{\Omega^{2}}{2}\left(x^{2}+y^{2}\right) \\
U & =\frac{G m_{1}}{r_{1}}+\frac{G m_{2}}{r_{2}} \\
r_{1} & =\sqrt{(x+\mu d)^{2}+y^{2}+z^{2}} \\
r_{2} & =\sqrt{[x-(1+\mu) d]^{2}+y^{2}+z^{2}}
\end{aligned}
$$

と定義すると，(22)〜 (24) 式は

$$
\begin{aligned}
\ddot{x}-2 \Omega \dot{y} & =\frac{\partial W}{\partial x} \\
\ddot{y}+2 \Omega \dot{x} & =\frac{\partial W}{\partial y} \\
\ddot{z} & =\frac{\partial W}{\partial z}
\end{aligned}
$$

と表わされる（25)の第一項は重力ポテンシャル，第二項は 遠心力を導くポテンシャルに対応している.

一方，ケプラーの第 3 法則 $G\left(m_{1}+m_{2}\right)=\Omega^{2} d^{3}$ を使うと，

$$
G m_{1}=(1-\mu) \Omega^{2} d^{3}, \quad G m_{2}=\mu \Omega^{2} d^{3}
$$

という関係が得られる。(32)式の関係式を考慮すると，(22) (24) 式は，角速度 $\Omega$ を用いて

$$
\begin{aligned}
\ddot{x}-2 \Omega \dot{y}-\Omega^{2} x=- & \frac{(1-\mu) \Omega^{2} d^{3}}{r_{1}^{3}}(x+\mu d) \\
& -\frac{\mu \Omega^{2} d^{3}}{r_{2}^{3}}[x-(1+\mu) d] \\
\ddot{y}+2 \Omega \dot{x}-\Omega^{2} y=- & \frac{(1-\mu) \Omega^{2} d^{3}}{r_{1}^{3}} y-\frac{\mu \Omega^{2} d^{3}}{r_{2}^{3}} y \\
\ddot{z}=- & -\frac{(1-\mu) \Omega^{2} d^{3}}{r_{1}^{3}} z-\frac{\mu}{r_{2}^{3}} z
\end{aligned}
$$

と表わされる。

\section{2 円制限三体問題の平衡点}

円制限三体問題においては，三体が特殊な配置にあると き平衡解をもつことが知られている，以下では，平面運動 $(z=\dot{z}=0)$ を考える. (33) (35)式の平衡点は, 2 天体を結ぶ 直線上 $(y=0)$ で重力と遠心力がつりあう直線解 $\left(L_{1}, L_{2}, L_{3}\right.$ 点とよぶ）と, $y \neq 0$ の三角形解 $\left(L_{4}, L_{5}\right.$ 点とよぶ $)$ に分類 


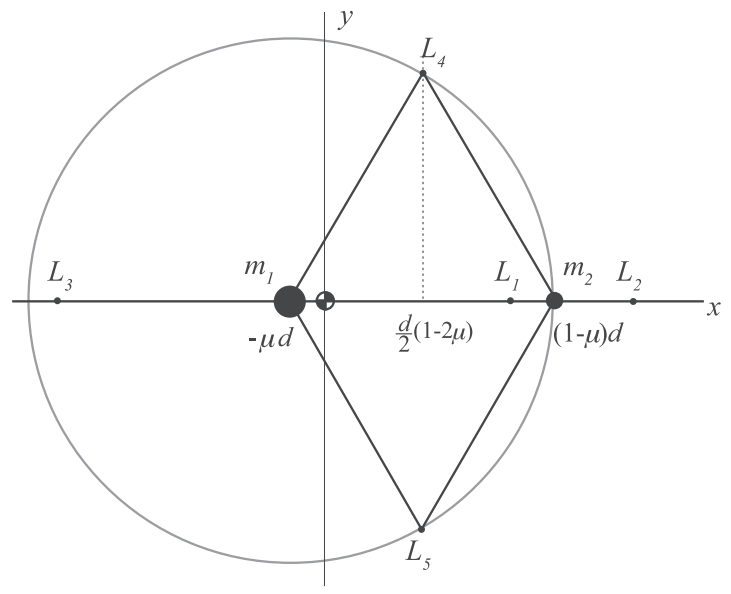

Fig. 6 Lagrangian points

され, 三角形解は, 2 天体を底辺とする正三角形の頂点

$$
\boldsymbol{r}_{0}=\left[\begin{array}{lll}
d / 2(1-2 \mu) & \sqrt{3} d / 2 & 0
\end{array}\right]^{T}
$$

で与えられる。これらの平衡点はラグランジュ点とよばれる

(Fig. 6).

つぎに，平衡点におけるシステム $(33) \sim(34)$ の安定性を考 える. $\boldsymbol{x}=\left[\begin{array}{cccc}x & y & \dot{x} & \dot{y}\end{array}\right]^{T}$ とおくと, $(33) \sim(34)$ 式の状 態方程式表現は,

$$
A_{0}=\left[\begin{array}{cccc}
\dot{\boldsymbol{x}}=A_{0} \boldsymbol{x}, & 0 & 1 & 0 \\
0 & 0 & 0 & 1 \\
0 & \left.\frac{\partial^{2} W}{\partial x \partial y}\right|_{\boldsymbol{r}=\boldsymbol{r}_{0}} & 0 & 2 \Omega \\
\left.\frac{\partial^{2} W}{\partial x^{2}}\right|_{\boldsymbol{r}=\boldsymbol{r}_{0}} & \left.\frac{\partial^{2} W}{\partial y^{2}}\right|_{\boldsymbol{r}=\boldsymbol{r}_{0}} & -2 \Omega & 0 \\
\left.\frac{\partial^{2} W}{\partial y \partial x}\right|_{\boldsymbol{r}=\boldsymbol{r}_{0}} &
\end{array}\right]
$$

となる。ここで $\boldsymbol{r}$ は原点から質点 $m$ へのベクトル (Fig. 5 参 照), $\boldsymbol{r}_{0}$ は質点 $m$ が平衡点にあるときの $\boldsymbol{r}$ である. 簡単のた め $\mu<0.5$ とする. 行列 $A$ の特性方程式は

$$
\lambda^{4}+\left(4 \Omega^{2}-a-c\right) \lambda^{2}+a c-b^{2}=0
$$

で与えられる。ここで

$$
a=\left.\frac{\partial^{2} W}{\partial x^{2}}\right|_{\boldsymbol{r}=\boldsymbol{r}_{0}}, b=\left.\frac{\partial^{2} W}{\partial x \partial y}\right|_{\boldsymbol{r}=\boldsymbol{r}_{0}}, c=\left.\frac{\partial^{2} W}{\partial y^{2}}\right|_{\boldsymbol{r}=\boldsymbol{r}_{0}}
$$

とおいた. $L_{1} \sim L_{5}$ 点の安定性を判定すると, $L_{1,2,3}$ はすべ ての $\mu$ で不安定であるのに対し, 正三角形解 $L_{4,5}$ 点におい ては， $\mu<0.03852$ で安定であることがわかる. 実際，固有 值は

$$
\begin{aligned}
\lambda_{1,2} & = \pm j \sqrt{\left.\frac{1}{2}+\frac{1}{2} \sqrt{1-27 \mu(1-\mu)}\right)}, \\
\lambda_{3,4} & = \pm j \sqrt{\left.\frac{1}{2}-\frac{1}{2} \sqrt{1-27 \mu(1-\mu)}\right)}
\end{aligned}
$$

で与えられる純虚数である. Fig. 7 に, 擬似ポテンシャル

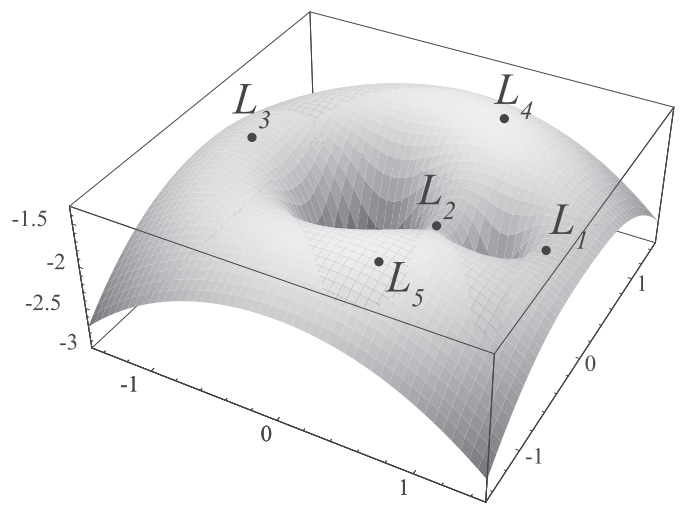

Fig. 7 Pseudo-potential and Lagrangian points

$W$ を示す. $L_{1,2,3}$ 点は曲面の鞍点, $L_{4,5}$ 点は極大点に位置 し，静的不安定であることがわかる，ここで，これらの平衡 点におかれた物体が平衡点からずれて速度をもって運動をは じめると，その速度に対して垂直な力であるコリオリカが働 く.このとき, $L_{4,5}$ 点に拈いては, ポテンシャル面の勾配と コリオリカの大きさがつりあって, 物体が安定化されている と解釈できる，一方， $L_{1,2,3}$ 点においては，同様にコリオリ 力は㗢くが，ポテンシャル面の勾配が大きく，結果的に不安 定になると解釈できる．また， $L_{1,2,3}$ はすべての $\mu$ で不安定 であるのに対し, 正三角形解 $L_{4,5}$ 点においては $\mu$ の条件に より安定となることがわかる.

\section{4. 円制限三体問題における陰的制御}

\section{1 陰的制御則}

前節の考察により, 円制限三体問題の $5 つ$ つ平衡点のうち, $L_{4,5}$ 点は他の平衡点にはない安定性をもつことがわかった. 2 章によると，制御系が与えられたとき，意図と制御対象と 場を定めるとそれに応じて陰的制御が定まってくるという図 式である. 円制限三体問題の $L_{4}$ 点での安定化問題において, 制御対象は質点 $m$ とすると, 質点に働く力である重力, 遠心 カ・コリオリカは, 制御対象が 2 天体の重力場, 2 天体とと もに回転する座標系の効果による遠心力・コリオリカに対応 する場におかれてはじめて生じる力であり，場と制御対象を 切り離すことにより消失する。これらの力を陰的制御と考え ると, 場の想定の仕方に自由度があるため, 以下の三つの場 合について考える。簡単のため $\Omega=1, d=1$ とし， $L_{4}$ 点に おける線形化方程式 (37)を考える.

状態方程式 (37) において, $L_{4,5}$ 点の安定性を生み出す 2 天 体の重力, 回転座標系による遠心力・コリオリ力を状態フィー ドバックとみなし，以下のように書き換える。

$$
\begin{aligned}
& \dot{\boldsymbol{x}}=A \boldsymbol{x}+B \boldsymbol{u}=A_{0} \boldsymbol{x} \\
& \boldsymbol{u}=-K \boldsymbol{x}
\end{aligned}
$$




$$
\begin{aligned}
A_{0} & =\left[\begin{array}{cccc}
0 & 0 & 1 & 0 \\
0 & 0 & 0 & 1 \\
\frac{3}{4} & \frac{3 \sqrt{3}}{4}(1-2 \mu) & 0 & 2 \\
\frac{3 \sqrt{3}}{4}(1-2 \mu) & \frac{9}{4} & -2 & 0
\end{array}\right], \\
B & =\left[\begin{array}{ll}
0 & 0 \\
0 & 0 \\
1 & 0 \\
0 & 1
\end{array}\right]
\end{aligned}
$$

であり, $\boldsymbol{u}=-K \boldsymbol{x}$ は陰的制御則とみなす状態フィードバック である. $A_{0}$ のどの部分を陰的制御と見なすかにより，A とし て以下の 3 種類のケースが考えられる. 閉ループ系 $A-B K$ は元のシステムと一致し,$\mu<0.03852$ で安定となっている. case (i)

$$
\begin{aligned}
& A=\left[\begin{array}{cccc}
0 & 0 & 1 & 0 \\
0 & 0 & 0 & 1 \\
-\frac{1}{4} & \frac{3 \sqrt{3}}{4}(1-2 \mu) & 0 & 0 \\
\frac{3 \sqrt{3}}{4}(1-2 \mu) & \frac{5}{4} & 0 & 0
\end{array}\right] \\
& K=-\left[\begin{array}{cccc}
1 & 0 & 0 & 2 \\
0 & 1 & -2 & 0
\end{array}\right]
\end{aligned}
$$

このとき, $A$ の固有値は

$$
\begin{aligned}
& \lambda_{1,2}= \pm \sqrt{\left.\frac{1}{2}+\frac{3}{2} \sqrt{1-3 \mu(1-\mu)}\right)}, \\
& \lambda_{3,4}= \pm j \sqrt{\left.-\frac{1}{2}+\frac{3}{2} \sqrt{1-3 \mu(1-\mu)}\right)}
\end{aligned}
$$

となり不安定極をもつことがわかる.

case (ii)

$$
\begin{aligned}
A & =\left[\begin{array}{llll}
0 & 0 & 1 & 0 \\
0 & 0 & 0 & 1 \\
1 & 0 & 0 & 2 \\
0 & 1 & -2 & 0
\end{array}\right], \\
K & =-\left[\begin{array}{cccc}
\text { - }^{-\frac{1}{4}} & \frac{3 \sqrt{3}}{4}(1-2 \mu) & 0 & 0 \\
\frac{3 \sqrt{3}}{4}(1-2 \mu) & \frac{5}{4} & 0 & 0
\end{array}\right]
\end{aligned}
$$

となり, $A$ の固有值は $\left(\lambda_{1,2}=0\right.$ (重根), $\lambda_{3,4}= \pm j$ (重根 $\left.)\right)$ となり, 安定である。

case (iii)

$$
A=\left[\begin{array}{llll}
0 & 0 & 1 & 0 \\
0 & 0 & 0 & 1 \\
0 & 0 & 0 & 0 \\
0 & 0 & 0 & 0
\end{array}\right],
$$

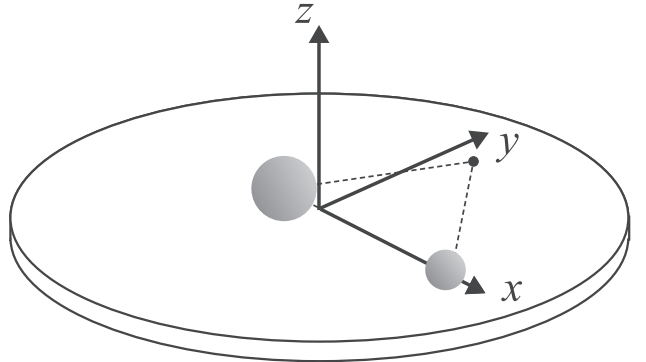

(a) Mass in the vicinity of the two bodies (case (i))

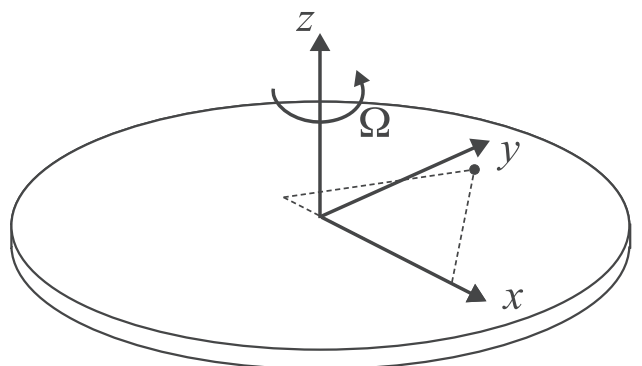

(b) Mass on rotating disk (case (ii))

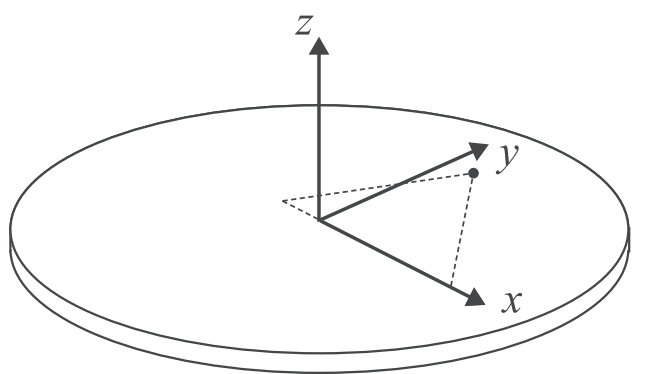

(c) Mass on disk (case (iii))

Fig. 8 Three types of plant and field

$$
K=-\left[\begin{array}{cccc}
\frac{3}{4} & \frac{3 \sqrt{3}}{4}(1-2 \mu) & 0 & 2 \\
\frac{3 \sqrt{3}}{4}(1-2 \mu) & \frac{9}{4} & -2 & 0
\end{array}\right]
$$

このとき, $A$ の固有值は $\lambda_{1,2,3,4}=0$ (4 重根) となり, 安定 である。

\section{2 陰的制御の物理的意味}

すべてのケースにおいて陰的制御は「虚軸上に全極を配置 する制御」とみなすことができる。ここで，2 天体の回転運動 は本来取り除くことができない効果であるが，回転運動の効 果の陰的制御の物理的意味をより明確にするため， 2 天体は 質量の無視できる棒でつながれているものと考える。このと き，陰的制御の物理的意味として以下のような解釈をするこ とができる. case (i) は, 2 天体の重力場において, 質点 $m$ を 一点 ( $L_{4}$ 点) に安定化する問題に対応する (Fig. 8 (a)). こ のとき, 質点 $m$ は 2 天体の重力により, 重心方向に引っ張ら れるのに対し，外向きの力である遠心力・コリオリ力を陰的 制御則とみなしている. case (ii) は角速度 $\Omega$ で回転する円盤 におかれた質点 $m$ を，円盤上の一点 $\left(L_{4}\right.$ 点) に安定化する問 題に対応する (Fig. 8 (b)).このとき, 制御入力がない状態で 
は, 質点 $m$ は遠心力・コリオリカにより $L_{4}$ 点から遠ざかる 向きに運動を行なう。平衡点を生み出している内向きの力で ある 2 天体からうける重力を，この系における陰的制御則と みなしている. case (iii) は, 2 天体も回転円盤も取り除かれ た，何もない状況に対応する (Fig. 8 (c)). このため遠心力 . コリオリ力, 重力すべての力を陰的制御則とみなしている.

\section{5. 円制限三体問題における陰的制御の特徵付け}

\section{1 陰的制御の $L Q$ 最適性からの特徵付け}

前節で述べた陰的制御 $\boldsymbol{u}=-K \boldsymbol{x}$ が最適制御の逆問題でい う $L Q$ 最適性を有するかどうかについて考察する. 前章で定 式化した円制限三体問題は, 本来, 力学系であるので, 位相 空間における軌道は, 最小作用の原理より, 作用積分の停留 值をとるような経路となっている ${ }^{11)}$. また, その線形化方程 式(37)に対応するハミルトニアンは一般化座標と一般化運動 量の二次形式となっている。この点に注目して本節では, こ の力学系の一部に対応する陰的制御 $\boldsymbol{u}=-K \boldsymbol{x}$ に制御理論的 な考察を加える。具体的には, 本制御が $L Q$ 最適性を有する か, また有するとしたらどのような評価関数に対して最適に なるのか, さらにその評価関数は一意に定まるのか, につい て考察を行ない, 陰的制御を $L Q$ 最適性の観点から非常に特 異な制御（ $L Q$ 最適性を最大限排除した制御）として特徵づ ける。

制御対象 (41) に対する陰的制御 (42)が，この $L Q$ 最適性を 有する, つまり $\boldsymbol{u}=-K \boldsymbol{x}$ が何らかの 2 次形式評価関数

$$
J=\int_{0}^{\infty}\left(\boldsymbol{x}^{T} Q \boldsymbol{x}+\boldsymbol{u}^{T} \boldsymbol{u}\right) d t
$$

を最小化するためには，少なくとも還送差条件

$$
\begin{aligned}
\Phi(j \omega) & =T(-j \omega)^{T} T(j \omega)-I \geq 0 \quad \text { a.e. } \omega \in R \\
T(s) & :=I+K(s I-A)^{-1} B
\end{aligned}
$$

が成立しなければならない。しかし, つぎに示すように, 陰 的制御系は閉ループ極がすべて虚軸上にあるため, 還送差条 件を満たさない.

定理 5.1. 閉ループ極をすべて虚軸上に配置するようなフィー ドバック制御 $\boldsymbol{u}=-K \boldsymbol{x}(K \neq 0)$ は，一般に還送差条件を 満足しない.

証明. 背理法で証明する. 最適制御の逆問題の結果より, $\boldsymbol{u}=-K \boldsymbol{x}$ が還送差条件を満たすとすると, 次式を満たす 実対称行列 $P \geq 0$ と評価関数の重み行列 $Q=C^{T} C \geq 0$ が 存在する ${ }^{12)}$.

$$
\begin{aligned}
& P A+A^{T} P-P B B^{T} P+Q=0 \\
& K=B^{T} P
\end{aligned}
$$

このリカッチ方程式に対応するハミルトン行列

$$
H=\left[\begin{array}{cc}
A & -B B^{T} \\
-Q & -A^{T}
\end{array}\right]
$$

は, 閉ループ行列 $A-B B^{T} P=A-B K$ と同じ固有值をも つから，虚軸上に 4 個の固有值をもつ。したがってリカッチ 方程式の解の性質 ${ }^{13)}$ から $A$ もこれら 4 個の固有值を $(Q, A)$ の不可観測モードとしてもつ． $A$ の全固有值が $(Q, A)$ の不 可観測モードとなるから $Q=0$ を得る。これをリカッチ方程 式 (51) に代入すると解 $P=0$ を得る。この解は

$$
\operatorname{Re} \lambda\left(A-B B^{T} P\right)=\operatorname{Re} \lambda(A)=0 \leq 0
$$

を満たすから (51)の最大解であり ${ }^{14)}$, 明らかに最小準正定解 でもあるから，準正定一意解である。ゆえに $(52)$ より $K=0$ となり，矛盾が生じる。

この結果より，陰的制御は通常の意味，つまり(49)の二次 形式評価関数に関して $L Q$ 最適性を有しないことがわかる. そこで, 評価関数を状態と入力のクロス積の項も含む準正定 二次形式

$$
J=\int_{0}^{\infty}\left(\boldsymbol{x}^{T} W_{11} \boldsymbol{x}+2 \boldsymbol{x}^{T} W_{12} \boldsymbol{u}+\boldsymbol{u}^{T} \boldsymbol{u}\right) d t
$$

のクラスに広げて考察してみる。一般に, 任意の $K$ を最適 制御にする評価関数の重み $W_{11}, W_{12}, W_{22}$ は無数に存在す ることが知られている。この事実は, 通常の 2 次形式評価関 数では文献 12)の系 8 で示されているが, 状態と入力のクロ ス項を含む (55)式の評価関数についても同様にして証明でき る.しかし，ここで考えている陰的制御については，つぎの 結果が得られる。

定理 5.2. 閉ループ極をすべて虚軸上に配置するようなフィー ドバック制御 $\boldsymbol{u}=-K \boldsymbol{x}(K \neq 0)$ は，(56)式の評価関数に 対してのみ最適になる。

$$
J=\int_{0}^{\infty}\left(\boldsymbol{x}^{T} K^{T} K \boldsymbol{x}+2 \boldsymbol{x}^{T} K^{T} \boldsymbol{u}+\boldsymbol{u}^{T} \boldsymbol{u}\right) d t
$$

証明. 評価関数 $(55)$ の重みをまとめて

$$
W=\left[\begin{array}{ll}
W_{11} & W_{12} \\
W_{12}^{T} & W_{22}
\end{array}\right] \geq 0
$$

と表わす。この評価関数に関する最適制御則 $K$ は下記のよ うにリカッチ方程式の解 $P$ を用いて

$$
P A+A^{T} P-\left(P B+W_{12}\right)\left(B^{T} P+W_{12}^{T}\right)+W_{11}=0
$$

$$
K=B^{T} P+W_{12}^{T}
$$

と表わされる。（57）にフィードバック変換 ${ }^{14)}$

$$
\begin{aligned}
A & \rightarrow F:=A-B W_{12}^{T}, \\
W_{11} & \rightarrow Q:=W_{11}-W_{12} W_{12}^{T}, \\
W_{12} & \rightarrow 0
\end{aligned}
$$

を施し，これを等価変形すると

$$
P F+F^{T} P-P B B^{T} P+Q=0
$$


を得る. 定理 5.1 の証明と同様に, リカッチ方程式 (59)に対 応するハミルトン行列, つまり $(53) て ゙ A$ を $F$ に置き換えたも のは，閉ループ行列

$$
F-B B^{T} P=A-B\left(B^{T} P+W_{12}^{T}\right)=A-B K
$$

と同じ固有值をもつから，虚軸上に 4 個の固有值をもつ。こ れをもとに以下同様にして $Q=0, P=0$ を得る。した

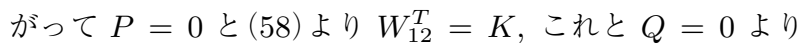
$W_{11}=W_{12} W_{12}^{T}=K^{T} K$ を得る.

逆にこのような重み $W$ に対して陰的制御 $\boldsymbol{u}=-K \boldsymbol{x}$ が （56）を最小化することは自明である.

全極を虚軸上に配置する陰的制御は, 定理 5.1 と 5.2 より, 1) 還送差条件も満足せず，2) 評価関数を一般化して状態と入力 の積の項を含めても, すべてのフィードバック制御 $\boldsymbol{u}=-K \boldsymbol{x}$ が共通に最適化する評価関数

$$
J=\int_{0}^{\infty}\|K \boldsymbol{x}+\boldsymbol{u}\|^{2} d t
$$

しか最小化しないことがわかる（一般には多数の評価を最適 化する)。このことから，㓌的制御は $L Q$ 最適性を最適性を 最大限排除した形になっていると解釈できる。あるいは，す ベての閉ループ極を虚軸上に配置することが強い制約として 働いており，その結果，評価関数を選択する自由度がなくな り，一意になってしまう，という解釈もできる.

\section{2 陽的制御を付加した陰的制御系の最適性について}

5.1 節の結果より，陰的制御は通常の二次形式評価関数に 関して $L Q$ 最適性を有しないことがわかった. また， $L_{4,5}$ 点 近傍の線形化方程式は虚軸上に極をもつ安定であり, 陰的制 御のみで漸近安定化することはできない，本節では，陰的制 御にある評価関数を最小化する陽的制御を付加することでシ ステムを漸近安定化する。その際に，4章で考えた 3 つの場 に対して，陽的制御 $\boldsymbol{u}=-K \boldsymbol{x}$ を以下のリカッチ方程式の解 $P$ を用いて設計する。

$$
\begin{array}{r}
P A_{0}+A_{0}^{T} P-P B B^{T} P+Q=0 \\
K=B^{T} P
\end{array}
$$

このとき，陽的制御は

$$
J=\int_{0}^{\infty}\left(\boldsymbol{x}^{T} Q \boldsymbol{x}+\boldsymbol{u}^{T} \boldsymbol{u}\right) d t
$$

という評価関数を最小化する安定化フィードバックとなって いる. $Q=q I\left(q=1,10,10^{8}\right), \mu=0.02$ に対応する陽的制 御のフィードバックゲインは

$$
\begin{aligned}
K_{1} & =\left[\begin{array}{cccc}
0.3632 & -0.9428 & 1.520 & -0.1523 \\
2.9699 & 3.9300 & -0.1523 & 2.8684
\end{array}\right] \\
K_{2} & =\left[\begin{array}{cccc}
3.3169 & -0.6166 & 3.9899 & 0.1713 \\
3.5984 & 5.8755 & 0.1713 & 4.7336
\end{array}\right]
\end{aligned}
$$

Table 1 Return difference condition

\begin{tabular}{cccc}
\hline \hline & case(i) & case(ii) & case(iii) \\
\hline$K_{1}$ & $\times$ & $\times$ & $\times$ \\
$K_{2}$ & $\times$ & $\circ$ & $\times$ \\
$K_{3}$ & $\circ$ & $\circ$ & $\circ$ \\
\hline \hline
\end{tabular}

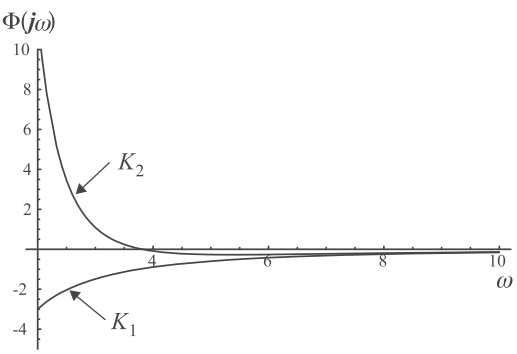

(a) $\Phi(j \omega)$ vs $\omega$ : Case (i)

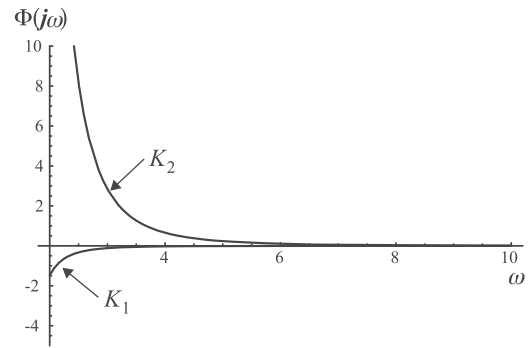

(b) $\Phi(j \omega)$ vs $\omega$ : case (ii)

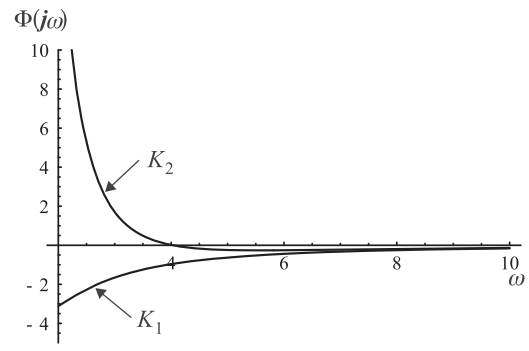

(c) $\Phi(j \omega)$ vs $\omega$ : case (iii)

Fig. 9 Return difference condition $\left(K_{1}, K_{2}\right)$

$$
K_{3}=10^{4} \times\left[\begin{array}{cccc}
1.0001 & -0.0001 & 1.0001 & 0.0000 \\
0.0003 & 1.0002 & 0.0000 & 1.0001
\end{array}\right]
$$

となる。これらの陽的制御と陰的制御をあわせたたものをひ とつの入力とみなし，その制御入力を加える前のシステムに 対して， $L Q$ 最適性をもつか調べた結果を Table 1 にまとめ る. case (i), (iii) では, 小さな $Q$ に対して還送差条件を満た さないのに対して, case (ii)では, ある大きさの $Q$ に対して は，還送差条件を満たしていることが数值計算により確認さ れた。つまり，重力項を陰的制御とみなした場合，それに陽 的制御を付加したものが， case (ii) のシステムに対して最適 性を有することがわかった。このことは，2.2 節の 1 入力系 の例題からの類推から十分大きな $Q$ を取れば最適となること に対応していると考えられる。その制御入力を加える前のシ ステムに対して，陽的制御のゲインを $K_{1}, K_{2}$ のとしたとき の還送差行列の行列式を調べた結果を Fig. 9 に示す.この 結果は理論的に保証されるものではないが，2 次系に対して 
は，陰的制御則と陽的制御則をあわせた制御則は，陰的制御 を除いたシステム $A$ に対しては必ずしも最適とならず, 最適 となるために満たすべき陰的制御と陽的制御の $Q$ の条件が示 されている15).

つぎに, 2 天体の質量比 $\mu$ を陽的制御を設計した值 $\mu=0.02$ から変化した場合の最適性を考える。このとき，陽的制御 $K_{2}$ は設計した $\mu=0.4$ で, 還送差条件を満たさなくなるのに対 して, 陰的制御と $K_{2}$ との和はすべての $\mu \in[0,1]$ で還送差 条件を満たすことがわかった。重力項を陰的制御とみなした 場合には, 質量比の変化により陰的制御は自動的に変更され, 最適性が維持されていると考えられる。このことから, 同一 のシステムであっても, 見方を変えることで, 最適性といっ た望ましい性質が得られることがあることがわかる.

\section{6. おわりに}

円制限三体問題における， $L_{4,5}$ 点の安定性を陰的制御の観 点から考察した. ラグランジュ点の安定性を生み出す 2 天体 の重力場, 回転座標系の効果による遠心力・コリオリ力を制 御対象と場との相互作用から生まれる陰的制御とみなし, 最 適性に関して考察した。 その結果, 陰的制御単独では, 通常 の意味での最適性をもたないこと, 評価関数にクロス積の項 を含む最適制御問題の解として評価関数が一意に決まるとい う興味深い結論が得られた。この「一意性」については, 一 意であるがゆえそこに物理的意味が見いだせるのではないか と推察している. 今後の課題である.ささらに, 陰的制御に最 適制御を付加した場合, システムのどの部分を制御対象と見 なすかにより最適性の違いが生まれることがわかった。この ことは, 従来の制御系設計において, 制御対象は固定的と考 えるのに対し，「どの部分までを制御対象と見るか」という問 題を考える必要性を示唆するものである.

円制限三体問題における質点の運動において，陰的制御と いう視点を導入することの可能性として，2つの可能性を考 えている. 1つ目は, 平衡点近傍での宇宙機の制御において, 場との相互作用を有効活用できる可能性がある点である。陽 的制御を付加して $L Q$ 最適にしょうとした意図は, 陰的制御 だけでは $L_{4}$ 点は漸近安定になっていないので，工学的にそ の点を活用するために, 陽的制御を加えることによって漸近 安定化したい，というところにある。その際，注目したのは， われわれが制御したいのは微小質点であり, 微小質点と陰的 制御則からなる制御系ではないということである。陰的制御 則と陽的制御則をあわせた制御則を考えることで, 微小質点 に対してダイレクトに制御則を設計するよりも，陰的制御則 という力学的作用力を巧く利用して設計した陽的制御則のほ うが何らかの意味で節約になる可能性が期待される．2 つ目 に, 平衡点近傍のダイナミクスを制御系と捉え, 制御系とし ての性質を知ることができる可能性がある。はじめにで述べ たように，2つの重心により近似できるピーナッツ型の形状 をもつ小惑星近傍の物体の運動もまた, 円制限三体問題と同 様の性質をもつ $\left.\left.{ }^{4)}, 5\right), 16\right)$. 小惑星のパラメー夕 (質量, 密度,
形状，自転速度など）は一般に，不確定性を多く含むため，平 衡点の安定性を論じることが難しいが, 制御工学的な解析を 用いることで小惑星近傍の平衡点の安定性の小惑星パラメー 夕に関するロバスト性などといった知見が得られると考えら れる.

謝辞 本研究の一部は, 最先端研究開発プログラム (FIRST), 「健康長寿社会を支える先端人支援技術」の助成 によるものである。

\section{参 考文 献}

1) 木下 宙: 天体と軌道の力学, 東京大学出版会 (1998)

2) C.D. Murray and S.F. Dermott: Solar system dynamics, Cambridge Univ Press (1999)

3）宇宙航空研究開発機構：小惑星イトカワの素顔に迫る—「はやぶ さ」科学的観測の成果一, http://www.jaxa.jp/article/special/ hayabusa_sp3/index_j.html

4) T. Prieto-Llanos and M.A. Gomez-Tierno: Stationkeeping at Libration Points of Natural Elongated Bodies, Journal of Guidance, Control, and Dynamics, 14-7, 787/794 (1994)

5) M. Hirabayashi, M.Y. Morimoto, H. Yano, J. Kawaguchi and J. Bellerose: Linear stability of collinear equilibrium points around an asteroid as a two-connected-mass: Application to fast rotating Asteroid 2000EB14, Icarus, 206, $780 / 782(2010)$

6）大須賀，石黒，鄭，杉本，大脇：制御系に埋め込まれた陰的 制御則が適応機能の鍵を握る!?，日本ロボット学会誌，28-4, 491/502 (2010)

7）大須賀公一：制御系における「埋め込み問題」とは? 一生物/ 人工物の運動制御機能の理解に向けて一，計測と制御，48-9, 493/499 (2009)

8）伊藤正美：自律分散システム, 文部省科学研究費補助金平成 2 4 年度研究成果報告書 (1994)

9）北村新三: 創発的機能形成のシステム理論, 文部省科学研究費 補助金研究の成果の概要と評価 (1998)

10）淺間 一：身体・脳・環境の相互作用による適応的運動機能の 発現一移動知の構成論的理解一, 平成 $17 \sim 21$ 年度研究成果報 告書 (2010)

11) H. Goldstein: Classical Mechanics, Addison-Wesley, Reading (1980)

12) 藤井隆雄：最適レギュレータの逆問題，計測と制御， 27-8, $717 / 726$ (1988)

13) V. Kucera: A Contribution to Matrix Quadratic Equations, IEEE Trans. Automatic Control, 17-3, 344/347 (1972)

14）須田，児玉：システム制御のためのマトリクス理論，コロナ社 (1981)

15) K. Osuka, T. Fujii and M. Bando: Optimality of Plugin Optimal Control, Proc. SICE Annual Conference, 2249/2250 (2011)

16）坂東, 大須賀, 藤井, 山川 : ピーナッッ形状小惑星のラグラン ジュポイントの安定性に関する陰的制御的考察, SICE 制御部 門講演会, 168-3-4 (2011)

\section{《付録》}

\section{A. 円制限三体問題の導出}

お互いに引力を及ぼしあって運動する 3 質点のハミルトニ アンは, 質点の運動エネルギーと双方向に作用する引力によ るポテンシャルエネルギーから構成される.

$$
H=\frac{\boldsymbol{p}_{1}^{T} \boldsymbol{p}_{1}}{2 m_{1}}+\frac{\boldsymbol{p}_{2}^{T} \boldsymbol{p}_{2}}{2 m_{2}}+\frac{\boldsymbol{p}_{3}^{T} \boldsymbol{p}_{3}}{2 m_{3}}
$$




$$
-\frac{G m_{1} m_{2}}{\left|\boldsymbol{r}_{1}-\boldsymbol{r}_{2}\right|}-\frac{G m_{2} m_{3}}{\left|\boldsymbol{r}_{2}-\boldsymbol{r}_{3}\right|}-\frac{G m_{3} m_{1}}{\left|\boldsymbol{r}_{3}-\boldsymbol{r}_{1}\right|}
$$

簡単のため $m_{1}+m_{2}=1$ として, 質量比 $\epsilon=\frac{m_{3}}{m_{1}+m_{2}}=$ $m_{3}<<1$ をパラメータとして級数展開すると

$$
\begin{aligned}
& H=H_{0}+\epsilon H_{1}+O\left(\epsilon^{2}\right) \\
& H_{0}=\left.H\right|_{\epsilon=0}=\frac{\boldsymbol{p}_{1}^{T} \boldsymbol{p}_{1}}{2 m_{1}}+\frac{\boldsymbol{p}_{2}^{T} \boldsymbol{p}_{2}}{2 m_{2}}-\frac{G m_{1} m_{2}}{\left|\boldsymbol{r}_{1}-\boldsymbol{r}_{2}\right|} \\
& H_{1}=\left.\frac{\partial H}{\partial \epsilon}\right|_{\epsilon=0}=\frac{\boldsymbol{p}_{3}^{T} \boldsymbol{p}_{3}}{2 m_{3}^{2}}-\frac{G m_{2}}{\left|\boldsymbol{r}_{2}-\boldsymbol{r}_{3}\right|}-\frac{G m_{1}}{\left|\boldsymbol{r}_{1}-\boldsymbol{r}_{3}\right|}
\end{aligned}
$$

$H_{0}$ は 2 体問題のハミルトニアンであり, ケプラー運動が解とな る. 解として, 円運動と仮定し, その解を $\left(\boldsymbol{q}_{10}, \boldsymbol{p}_{10}\right),\left(\boldsymbol{q}_{20}, \boldsymbol{p}_{20}\right)$ とする. この解を摂動ハミルトニアン $H=H_{0}+\epsilon H_{1}$ に代 入すると，

$H=\left.H_{0}\right|_{\left(\boldsymbol{r}_{10}, \boldsymbol{p}_{10}\right),\left(\boldsymbol{r}_{20}, \boldsymbol{p}_{20}\right)}+\frac{\boldsymbol{p}_{3}^{T} \boldsymbol{p}_{3}}{2 m_{3}^{2}}-\frac{G m_{2} m_{3}}{\left|\boldsymbol{r}_{3}-\boldsymbol{r}_{20}\right|}-\frac{G m_{1} m_{3}}{\left|\boldsymbol{r}_{3}-\boldsymbol{r}_{10}\right|}$

となり, 微小質点 $m_{3}$ の運動方程式が導かれる (円制限三体 問題).

$m_{3} \ddot{\boldsymbol{r}_{3}}=-\frac{G m_{2} m_{3}}{\left|\boldsymbol{r}_{3}-\boldsymbol{r}_{20}\right|^{3}}\left(\boldsymbol{r}_{3}-\boldsymbol{r}_{20}\right)-\frac{G m_{1} m_{3}}{\left|\boldsymbol{r}_{3}-\boldsymbol{r}_{10}\right|^{3}}\left(\boldsymbol{r}_{3}-\boldsymbol{r}_{10}\right)$

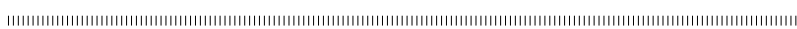

\section{[著者紹介]}

\section{坂 東 麻 衣 (正会員)}

2008 年京都大学工学研究科航空宇宙工学専攻修 了. 同年京都大学生存圈研究所ミッション専攻研 究員, 2010 年京都大学宇宙総合学研究ユニット特 定助教, 現在に至る. 宇宙機の軌道力学・制御工 学に従事. 博士 (工学).

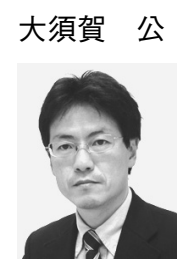

- (正会員)

1984 年大阪大学大学院基礎工学研究科修士課程 (制御工学) 修了. 同年 (株) 東芝入社, 総合研究 所勤務. 86 年大阪府立大学工学部助手. その後, 講師, 助教授を経て, 98 年京都大学大学院情報学 研究科助教授, 2003 年神戸大学工学部教授, 2009 年大阪大学大学院工学研究科機械工学専攻教授と なり現在に至る、ロボティクス, 制御工学, レス キュー工学などの研究に従事. 工学博士.

\section{藤 井 隆 雄 (正会員)}

1969 年大阪大学大学院基礎工学研究科博士課程 中途退学. 同大学助手, 助教授を経て, 90 年九州 工業大学情報工学部教授, 95 年大阪大学基礎工学 部教授, 2006 年福井工業大学工学部教授, 現在に 至る. 制御理論とその応用に関する研究に従事. 工学博士.

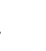

山川宏（正会員）

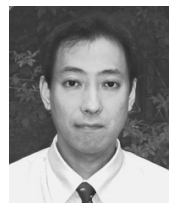

1993 年東京大学大学院工学系研究科航空科専攻 修了. 同年宇宙科学研究所助手, 99 年同助教授, 2003 年 JAXA 助教授, 2006 年京都大学生存圈研 究所教授，現在に至る。宇宙機の軌道工学，宇宙 システム工学の研究に従事. 博士 (工学). 